\title{
Effects of Pulsatile and Non-Pulsatile Perfusion On Oxygenator Fibers During Pediatric Cardiopulmonary Bypass
}

\author{
Taylan Gazioğlu ${ }^{1}$, Mustafa Kocakulak ${ }^{2}$, Fatma Ayhan ${ }^{3}$, Hakan Ayhan ${ }^{4 *}$ \\ ${ }^{1}$ Hacettepe University, Institute of Pure and Applied Science, Bioengineering Div., Ankara, Turkey. (ORCID: 0000-0003-0225-9887), taylangazioglu00@ yahoo.com \\ ${ }^{2}$ Democracy University, Faculty of Engineering, Biomedical Engineering Department, İzmir, Turkey (ORCID: 0000-0001-5029-0104), mustafa.kocakulak@ gmail.com \\ ${ }^{3}$ Muğla Sitkı Koçman University, Faculty of Science, Department of Chemistry, Biochemistry Division, Biochemistry\&Biomaterials Research Group, Muğla, Turkey, \\ (ORCID: 0000-0003-2220-4496), fayhan@mu.edu.tr \\ 4*Muğla Sıtkı Koçman University, Faculty of Science, Department of Chemistry, Biochemistry Division, Biochemistry\&Biomaterials Research Group, Muğla, Turkey, \\ (ORCID: 0000-0003-2911-1655), hayhan48@gmail.com
}

(First received 1 June 2021 and in final form 21 August 2021)

(DOI: $10.31590 /$ ejosat.917027)

ATIF/REFERENCE: Gazioğlu, T., Kocakulak, M., Ayhan, F. \& Ayhan, H. (2021). Effects of Pulsatile and Non-Pulsatile Perfusion On Oxygenator Fibers During Pediatric Cardiopulmonary Bypass. European Journal of Science and Technology, (27), 193203.

\begin{abstract}
In cardiopulmoner operations patients can be perfused with a pulsatile or nonpulsatile pump mode. The extra energy maintained by the pulsatile perfusion may have different effects on the patient and the oxygenator fiber rather than nonpulsatile perfusion. Especially the effect of pulsatile perfusion on the fibers isn't clearly known. The purpose of this study is to investigate the effects of pulsatile and non-pulsatile blood flows on oxygenator fibers. 18 out of 32 patients that had an pediatric open heart surgery was chosen according to their aortic clamp times. 9 of 18 patients were perfused in a pulsatile mode, other 9 patients were perfused in a nonpulsatile mode. The patient blood was collected before the open heart surgery (T1), before aortic clamp (T2), after aortic clamp (T3), after 1st intensive care hour (T4) and after the 1st intensive care day (T5) in order to compare the results of whole blood and plasma proteins. At the end of the open heart operation $10 \mathrm{~cm}$ of oxygenator fiber was removed from the fiber bundle and taken into the phosfate buffer saline (PBS) solution after the patient had a stabile outcome. Whole blood and micro protein measurements were applied in both first fiber solution and sonicated solution. No harmful effect of pulsatile perfusion on blood cells and proteins was observed according to patient results. More blood cell aggregation and total protein adsorption was observed in nonpulsatile mode fibers results. In this study pulsatile perfusion maintained better blood compability over nonpulsatile perfusion and the extra energy in pulsatile perfusion caused better microcirculation.
\end{abstract}

Keywords: Pediatric Cardiopulmonary Bypass, Extracorporeal Circulation, Pulsatile Perfusion, Nonpulsatile Perfusion, Biocompability, Hemacompability.

\section{Pediatrik Kardiyopulmoner Kalp Ameliyatlarında Pulsatil ve Pulsatil Olmayan Perfüzyonun Oksijenatör Fiberleri Üzerindeki Etkileri}

$\ddot{O} \mathbf{z}$

Açık kalp ameliyatlarında hastalar pulslu ve pulssuz olmak üzere iki şekilde perfüze edilebilmektedir. Pulslu akışın, pulssuz akışa göre sahip olduğu yüksek enerjinin hastaya ve oksijenatör fiberine farklı etkileri olabilmektedir. Özellikle pulslu perfüzyon tipinin oksijenatör fiberleri üzerine etkileri tam olarak bilinmemektedir. Çalışmanın amacı pulslu ve pulssuz perfüzyonun oksijenatör fiberleri üzerine etkilerinin araştırılmasıdır. Pediatrik açık kalp ameliyatı geçiren 32 hastadan 18 'i uygun aortik çapraz kıskaç sürelerine göre seçilerek çalışmaya dahil edilmiştir. 18 hastadan 9 çocuk hastaya pulslu, 9 çocuk hastaya pulssuz perfüzyon uygulanmıştır. Kardiyopulmoner bypas öncesi (T1), aorta çapraz kıskaç ile kapatıllığında (T2) ve açıldığında (T3), yoğun bakım 1. Saatte (T4) ve 24. Saatte (T5) olmak üzere 5 ayrı zaman diliminde tam kan ve plazma proteinleri ölçümlerinin karşılaştırılması için hasta kanları toplanmıştır. Açık kalp ameliyatı sonlandığında ve hastanın yaşamsal belirtileri sabitlendiğinde, kullanılan vücut dışı dolaşım devresinde oksijenatör çıkartılmış, fiber bölgesinden $10 \mathrm{~cm}$ 'lik fiber parçaları alınarak PBS çözeltisine konmuştur. Fiberlerin bulunduğu bu çözeltide tazelenen ve sonikasyon işlemine tabi tutulan yeni çözeltide tam kan ve mikro-protein ölçümleri yapılmıştır. Hasta sonuçlarına göre pulslu perfüzyonun kan hücrelerine ve plazma proteinlerine olumsuz bir etkisi görülmemiş̧tir. Fiber sonuçlarına bakıldığında sonike edilmiş fiberlerde pulssuz grupta bir miktar daha fazla eritrosit, lökosit ve total protein yüzeye tutunması tespit edilmiştir. Pulslu perfüzyon daha iyi kan uyumluluğu sağlamıştır ve sahip olduğu yüksek enerjiyle daha iyi mikrodolaşım yaratmıştır.

Anahtar Kelimeler: Pediatrik Kardiyopulmoner Bypass, Ekstrakorporal Dolaşım, Pulslu Perfüzyon, Pulssuz Perfüzyon, Biyouyumluluk, Kan Uyumluluğu.

* Corresponding Author: hayhan48@ gmail. 


\section{Introduction}

The cardiapulmonary functions are attained by heart and lung machine, an extracorporeal device, during the large part of cardiopulmoner operations. Doctors often have no alternative rather than this method even if it leads to the disintergration of formed elements of blood, prolongation of healing process and malfunction of organs and tissues at times. In cardiopulmonary operations, patients can be perfused with a pulsatile or nonpulsatile pump mode. Since there are no many studies showing the effects of pulsatile perfusion, it is not clearly known when to apply pulsatile perfusion. On the other hand, nonpulsatile perfusion is employed more frequently than pulsatile one. Studies carried out until now demonstrates the superiority of pulsatile perfusion over nonpulsatile one in terms of tissue metabolism, organ oxygenation and microcirculation (Dündar et. al., 1999; Kocakulak et. al 2005).

However, pulsatile perfusion gives damage to formed elements of blood because it provides blood circulation with high pressure (Qian, 1994; Wright, 1986). Nonpulsatile perfusion enables the blood to flow around the body with the same velocity and pressure but this type of flow is not of physiological nature. Pulsatile perfusion ensures a physiological blood flow similar to that of cardiac and puts a supplement hydraulic power and pressure to use. In extracorporeal circulation, the blood of patients contacts with unfamiliar surface areas and confronts mechanical effects, causing various changes in blood components. The high shear stress of pulsatile perfusion may harm formed elements of blood more than that of nonpulsatile perfusion (Qian, 1995).

Hollow fiber oxygenators are more preferred by the producers of commercial oxygenators due to some deficincies of membrane and bubble oxygenators. Hollow fiber oxygenators are appropriate for the application of pulsatile and nonpulsatile perfusion. Fibers provide an increase in performance of oxygenators and blood-fiber contact surface, a better $\mathrm{O}_{2}-\mathrm{CO}_{2}$ transfer and a decrease in harmful effects of fibers on blood by reducing surface of contact.

Therefore, the optimization of surface areas is one of the most important research-development issues of commercial firms. An oxygenator is a cruical element of extracorporeal system. The interaction between blood-oxygenator fiber has not been widely researched. The disintegration of formed elements of blood during the gas exchange capacity and use of oxygenators is an important field of research. With a surface area of $1.7 \mathrm{~m}^{2}-2.6 \mathrm{~m}^{2}$, membrane is where blood is oxygenated and the majority of interactions between blood components takes place (Segers 2001).

When the blood of patient starts to travel around the body extracorporeally, plasma proteins and blood cells adhere to extracorporeal lines and oxygenators (Kirklin 1983). The fiber of oxygenator is the most important part where adherence occurs.

This study aims to examine the effects of pulsatile and nonpulsatile perfusion on patients and oxygenator fibers. The effects and type of surgeries are taken into account as well. In doing so, the differences between pulsatile and nonpulsatile perfusions are to be found and the choice of perfusion type is to be facilitated.

\section{Material and Method}

This study aims to find out the effect of heart-lung machine, which is used in extracorporeal circulation during open heart surgeries, on oxygenator fibers druing pulsatile and nonpulsatile perfusions. Thus, the effects of pulsatile and nonpulsatile perfusions on patients and oxygenator fibers are togehter examined. The section below explains the conduction of the study, the materials to be used and their effects on the study.

\subsection{Patients}

The operations were performed by the surgeons of Başkent University, Department of Cardiology. 18 out of 32 patients (up to 14 years of age), who underwent pediatric open heart surgery, are selected regarding aortic clamp periods and included in this study (Table 1). The reason is that the damages to formed elements of blood tend to increase as a result of extracorporeal circuit. This increase especially reaches top in aortic crossclamping process when circulation is provided by a pump. For this reason, 18 patients whose timing of aortic cross-clamping treatments were near are selected. Half of these patients experienced pulsatile, the other half nonpulsatile perfusion. The team performing open heart surgeries was composed of the surgeons and their assistants, anaesthetists and their assistants, perfusionist responsible for the use of heart-lung machine, personnels responsible for the provision of operation tools and nurses.

\section{Table 1. Patients}

\begin{tabular}{|c|c|c|}
\hline & Pulsatile & Nonpulsatile \\
\hline Total Patients & 9 & 9 \\
\hline No of Patients M/F (female) & 3 & 6 \\
\hline No of Patients M/F (male) & 3 & 3 \\
\hline Age (month) & $17.2 \pm 12.8$ & $18.3 \pm 13.2$ \\
\hline Operation & & \\
\hline VSD & 4 & 4 \\
\hline ASD & 2 & 2 \\
\hline ASD+VSD & 1 & \\
\hline TOF & 1 & 2 \\
\hline Senning & - & 1 \\
\hline DSM & 1 & - \\
\hline
\end{tabular}

\subsection{Anesthesia}

Pavulon, dormicum and fentanyl anesthetic agents are given intravenously to patients by injecting catheter into axillary artery and peripheral vein. Following the placing of a tube into the windpipe, the patient is connected to a mechanised ventilator. Oxygen and anesthetic agents are given to patient by using the ventilator

\subsection{Perfusion}

Pediatric patients have a faster metabolic rate and more blood per kg than adults. Therefore, pediatric patients need more oxygen. Their heat loss rates are higher (Table 2 ). The flow rate under normal conditions is $2.4 \mathrm{~L} / \mathrm{m}^{2} / \mathrm{min}$. There are many formulas to measure the body surface area of the patient. S. Anderson's formula is as follows: $\mathrm{m}^{2}=[(\mathrm{kgx} 4)+7] /(90+\mathrm{kg})$ Determination of flow is: Flow $=\mathrm{m}^{2} \mathrm{x}$ cardiac index (C.I). Cardiac index is the amount in liter/min $/ \mathrm{m}^{2}$. These values are shown in Table 3. 
Even though the cardiac index is higher among pediatric patients, an amount of 1-1.5 liter proves to be adequate for total flow since pediatric patients have a lower weight and a smaller body surface area.

Table 2. Information about Perfusion.

\begin{tabular}{|l|c|c|}
\hline & Pulsatile & Nonpulsatile \\
\hline Pulse (no/min.) & 123 & 131 \\
\hline Area $\left(\mathrm{m}^{2}\right)$ & 0.41 & 0.44 \\
\hline Flow (lt/min) & 1142 & 1255 \\
\hline Priming solution (ml) & $1075 \pm 175$ & $1125 \pm 150$ \\
\hline Time of Bypass (min.) & $72 \pm 18$ & $71 \pm 19.5$ \\
\hline $\begin{array}{l}\text { Aortic cross-clamp } \\
\text { period (min.) }\end{array}$ & $49.5 \pm 16.5$ & $47.5 \pm 19.5$ \\
\hline
\end{tabular}

Table 3. Cardiac index rates according to age.

\begin{tabular}{|c|c|}
\hline Age & Cardiac index \\
\hline $0-1$ & 3 \\
\hline $1-2$ & 2.8 \\
\hline $2-3$ & 2.7 \\
\hline $3-4$ & 2.6 \\
\hline $4-12$ & 2.5 \\
\hline $12+$ & 2.4 \\
\hline
\end{tabular}

\subsection{Pulsatile and Nonpulsatile Flow}

The rate of nonpulsatile flow among patients are determined by considering age, weight and body surface area. Given the nature of nonpulsatile perfusion, perfusions are applied continously in patients. The pulsatilely perfused patients have a perfusion which causes a $30-35 \mathrm{mmHg}$ pressure in radial artery by adjusting a minimum pulse wave value which is $25-30 \%$ of the maximum value with a pulse-width of $50 \%$, and equalizing the pulsating rate per minute. A control button on the pulsatile pump helps start pulsatile perfusion. Figure 1 indicates the passage from nonpulsatile flow to pulsatile one.

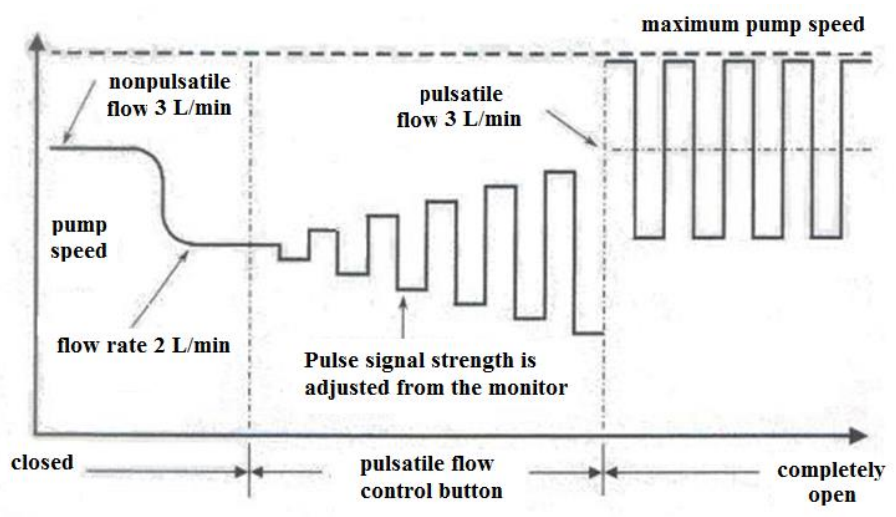

Figure 1. Pulsatile and Non-pulsatile flow demonstration

\subsection{Protection of Myocardium}

$80 \mathrm{ml}$. blood flow is normally adequte for $100 \mathrm{gr}$. Myocardium. This need is ten times bigger than that of the other body tissues. This is because myocardium entails higher amount of energy. Besides, skeletal muscle consume $25 \%$ of the oxygen in blood whereas the consumption of myocardium is $75 \%$. The cardiac requires blood circulation with a high level. The body temperature of the patient is reduced to $24-26^{\circ} \mathrm{C}$ on average for the protection of myocardium. As a result, the need for oxygen and nutrient diminishes. Plus cold cardioplegia is given. The e-ISSN: 2148-2683 reason is to prevent the consumption of energy by disallowing the working of cardiac under ischemic conditions following aortic clamping. For this, following aortic closure with a clamp, cold cristalloid cardioplegia solution is given from aortic root through anterograde cannula and from coronary ostium through retrograde cannula and cold blood cardioplegia solution is given with 20-minute intervals. There is a high amount of potassium, $\mathrm{K}^{+}$, in the solution to prevent the heart from stopping. The ingredients of cardioplegia solution are as follows: $25 \mathrm{ml}$ Potassium, $6 \mathrm{ml}$ Magnesium sulfate, $6 \mathrm{ml}$ citrate, $1 \mathrm{ml}$ sodium bicarbonate, $200 \mathrm{ml} \mathrm{10 \%} \mathrm{dextrose.}$

\subsection{The collection of blood samples}

For the tests to be performed in 5 different time intervals, the samples are collected in 5 ml-biochemistry tubes with gel (SST 2, BD, England), $2.7 \mathrm{ml}$-fibrinogen citrate tubes (9NC, $\mathrm{BD}$, England) and $4 \mathrm{ml}$-EDTA tubes (K2E, BD, England). The time intervals are such: before T1-Open heart surgery, T2-the aortic closure with cross clamping, T3-the aortic disclosure of cross clamping, T4-intense care first hour and T5-intense care 24. hour.

\subsection{The collection of fiber samples from oxygenators}

When the open heart surgery is finalized and the life conditions of the patients becomes stable again, the oxygenator is removed in extrcorporeal circuits. The external cover of the removed oxygenator is opened by a diamond coated cutter. 300 fibers with an approximate lenght of $10 \mathrm{~cm}( \pm 10 \%)$ are extracted from the oxygenator by a surgeon's knife under sterilized conditions. The extracted fibers are put into $40 \mathrm{ml}$-sterilized containers with $10 \mathrm{ml}$ sterile serum physiological solutions.

\subsection{Studies with blood samples}

The operations are performed at Başkent University Hospital, Department of Cardiovascular Surgery and the blood analysis obtained at five different time intervals are made at Gülhane Military Medical Academy, Department of Biochemistry. Complete blood counts are made by Cell-Dyn 4000 (Abbott Diagnostics, USA) cell counter and the biochemical tests are performed by Olympus AU2700 (Olympus Diagnostics, Japan) autoanalyzers and coagulation tests are made by Amax 190 (Tokra, Turkey) devices. The tests determine the total amount of: Proteins, Erythrocytes, Platelets, Haematocrits, Haemoglobins, Fibrinogens, Albumins and Bilirubins.

\subsection{Studies with oxygenator fibers}

After the open heart surgery, fibers from oxygenator put into $10 \mathrm{ml}$-serum physiological containers are taken into $10 \mathrm{ml}-$ serum physiological containers again and are sonicated for 2 hours. 2 solutions, one from oxygenator fibers and the other one taken from oxygenator fibers and sonicated, are obtained as a result. All the same blood and biochemical tests are performed on these two solutions and it the effects of pulsatile and nonpulsatile perfusion on fibers are tried to be understood. The measuremets are realized by increasing the sensitiveness of the devices. 


\section{Results and Discussion}

The aim of this study is to reseach the effects of pulsatile and nonpulsatile perfusion on oxygenator fibers and on the healing process of the patients. For this reason, 18 patients are included in this study. 5 blood samples of each patients are obtained at five different time intervals and biochemical and complete blood counts are realized. At the end of the operations, the fibers are extracted from oxygenators and they are stored in $10 \mathrm{ml}$ serum physiological solutions. These fibers, then, are taken into $10 \mathrm{ml}$ serum physiological solutions and sonicated for two hours. Biochemical tests and complete blood counts of the first group of sonicated fiber solutions are realized and microprotein and blood cells are investigated. The periods and abbreviations are defined as: before T1: Open heart surgery, T2: the aortic closure with cross clamping, T3: the aortic disclosure of cross clamping, T4: intense care first hour and T5: intense care 24.hour.

\subsection{The results obtained from blood samples}

\subsubsection{Results of blood cells}

This section of the study shows the analysis of blood cells made at five different time intervals among patients who experienced pulsatile and nonpulsatile perfusion. The determination of erythrocytes, leucocytes, haemoglobins and haemotocrits are made. All complete blood tests and analysis of the 9 patients selected from each group are made. The average results of each group are determined and each parameter is shown, analyzed and discussed below in a detailed way.

\subsubsection{Erythrocytes (red blood cells)}

During the extracorporeal circulation of blood, there appear changes in the amount of blood cells due to their contact with foreign substances and mechanical effects. The preliminary solution of oxygenator and the mechanical effects of the pumps cause haemolysis and the number of erythrocytes decrease when the operation begins. This case was reported by Martin R. and his colleagues in 1989. When the amount of erythrocytes are examined in Figure 2, it is seen that the preliminary average of nonpulsatile group is $4.3 \times 10^{6}$ cells $/ 1 \mathrm{~mm}^{3}$; it is $3.7 \times 10^{6} / 1 \mathrm{~mm}^{3}$ among pulsatile group. There appears no important difference between these two groups. When operation begins (T2), the aveage eryhtrocycte amount starts to decrease because of blood trauma and hemodilution. The number of RBC becomes $3.7 \times 10^{6}$ cell $/ \mathrm{mm}^{3}$ for nonpulsatile and $3.4 \times 10^{6}$ cell $/ \mathrm{mm}^{3}$ for pulsatile group. During the operation, the amount of eryhtrocyctes remains stable because blood is given to patient when required in order to keep the haemotocrite value on credible boundaries. Therefore, following the aortic clossure of cross clamping, the erythrocyte amounts become $3.6 \times 10^{6}$ cell $/ \mathrm{mm}^{3}$ for each group in T3. In T4, the first hour of intense care, blood is continuously given to the patient. This is why there appears an increase of eryhtrocytes in the pulsatile group more than that of nonpulsatile one. The average erythrocycte amounts of nonpulsatile and pulsatile groups are found to be $5.2 \times 10^{6}$ cell $/ \mathrm{mm}^{3}$ and $5.6 \times 10^{6}$ cell $/ \mathrm{mm}^{3}$, respectively. In $\mathrm{T} 5$ of first day-intense care, the erythrocycte amounts decrease and reach normal levels. The erythrocycte amounts of nonpulsatile and pulsatile groups occur to be $4.5 \times 10^{6}$ cell $/ \mathrm{mm}^{3}$ and $4.7 \times 10^{6}$ cell $/ \mathrm{mm}^{3}$, respectively. A general evaluation is made and it is found out that there occurs no such important difference between these two groups at the end of the operation and during intense care period. However,

e-ISSN: 2148-2683 the patients of nonpulsatile group tend to protect erthrocyctes better than the pulsatile group during the healing processes of the patients. This is why it is easier to comment that pulsatile perfusion is better than nonpulsatile perfusion in terms of healing of patients and blood compatibility. In 1994, Wright M. and his colleagues showed that pulsatile perfusion provided a microcirculation better than that of nonpulsatile perfusion and for that reason, pulsatile perfusion makes it more efficient for eryhtocyctes to join blood circulation after operation (Martin et. al., 1989; Wright 1994).

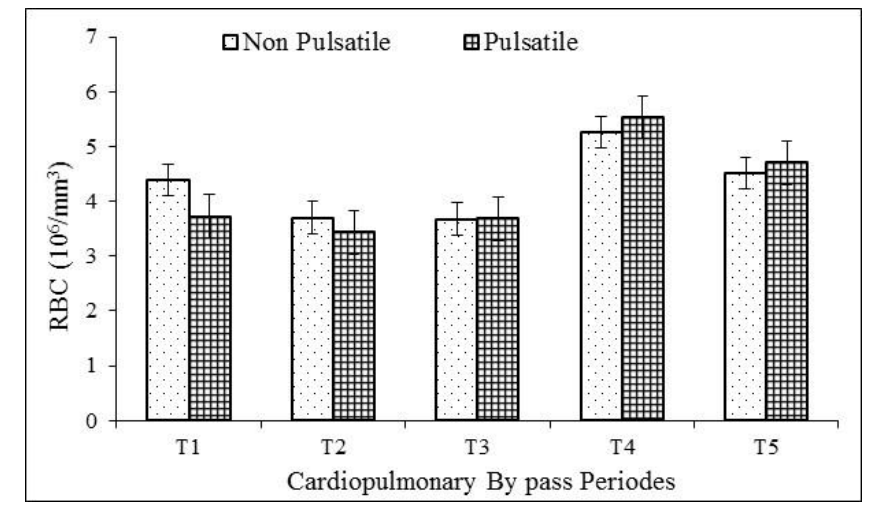

Figure 2. Erythrocytes (RBC) at 5 different time intervals during Cardiopulmonary Bypass Periode.

\subsubsection{Leucocytes (white blood cells)}

Figure 3 shows the amounts of leucocytes of each group before the operation. A healthy child has $3.000-10.000 \mathrm{cell} / \mathrm{mm} 3$ of leukocytes. The amounts of leucocytes of the two groups are found similar before operation. In T1 during operation, the average amounts of leucocytes of nonpulsatile and pulsatile groups are $8.700 \mathrm{cell} / \mathrm{mm}^{3}$ and $8.300 \mathrm{cell} / \mathrm{mm}^{3}$, respectively. In $\mathrm{T} 2$, the average leucocyte values for nonpulsatile and pulsatile groups are $5.300 \mathrm{cell} / \mathrm{mm}^{3}$ and $4.800 \mathrm{cell} / \mathrm{mm}^{3}$, respectively. This is in accordance with literature as well. The amount of leucoctyes tend to decreas as a result of blood's contact with foreign substances in hemodilution and perfusion. In T3 when cross clamping is removed from aort, the amount of leucocyte starts to increase and the average amount of leucocytes of nonpulsatile and pulsatile groups become $5.600 \mathrm{cell} / \mathrm{mm}^{3}$ and 7.100 cell $/ \mathrm{mm}^{3}$, respectively. In T4 and T5 of intence care, the amounts of lecocytes continue to rise constantly. The average amount of leucocytes of nonpulsatile and pulsatile groups occur to be $10.600 \mathrm{cell} / \mathrm{mm}^{3}$ and $11.500 \mathrm{cell} / \mathrm{mm}^{3}$ in $\mathrm{T} 4$, respectively; in T5, the amounts are $13.900 \mathrm{cell} / \mathrm{mm}^{3}$ and $14.800 \mathrm{cell} / \mathrm{mm}^{3}$ for nonpulsatile and pulsatile groups, respectively. It can be said that the difference in rise between two groups is not considerable but it is higher in pulsatile group. The contact of blood with extracorporeal circuit increases the production of leucocyte cells in blood. In 1983, Kirklin and his colleagues had reported that the contact of blood with extracorporeal circuit increased the production of leucocytes in blood during open heart surgery (Kirklin 1983). After open heart surgery, the amount of leucocyte increase rapidly. This increase is more evident when heating is restored and aortic cross clamping is removed. This was reported by Quiroga and his colleagues in 1985 (Quiroga et. al., 1985). The come-back of the original amount of leucocytes after operation is considered to be the result of the increase of body temperature and blood flow in bone marrow. It is observed that the leucocyte increase tends to continue a couple of days 
after the operation. It is possible to reach the result that extracorporeal circuits causes plasma proteins, platelets and leucocytes adhere to surface and this partially affects the general biocompatibility of the system. In addition, another study indicates that platelets and leucocytes combine, form clusters and join the blood circulation and leads to pulmonary dysfunction by adhering to pleura in spite of all measures taken against the blood-extracorporeal circuit contact (leucocyte filterheparinization of circuit etc.) (Kirklin 1983).

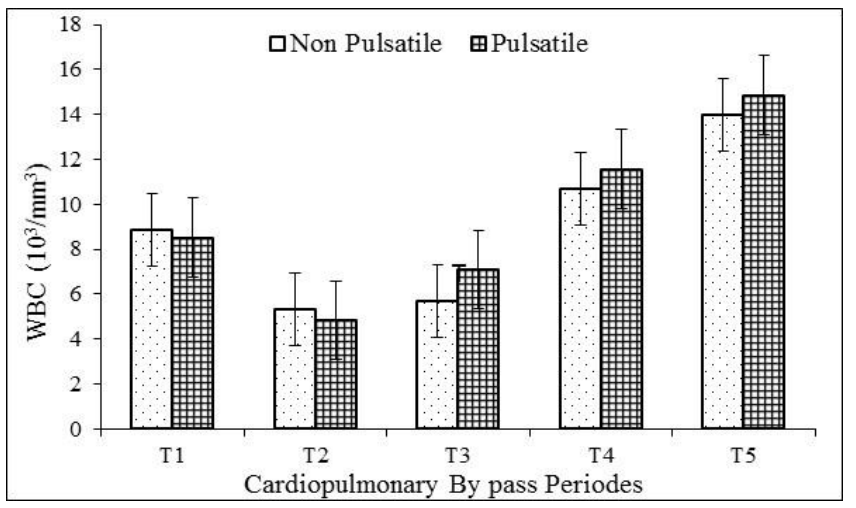

Figure 3. Leucocytes (WBC) at 5 different time intervals during Cardiopulmonary Bypass Periode.

\subsubsection{Haemoglobin}

During and after the operation, it is important to measure and control the level of haemoglobin in case of oxygenations of tissues and organs. Under normal conditions, the haemoglobin level of children is $10-13 \mathrm{~g} / \mathrm{dl}$. The amount of haemoglobin, a molecule bound to oxygen in erythrocyte, in blood is compatible with that of eryhtrocyte in Figure 4. The haemoglobin levels of patients of each group are given in Figure 12. The preliminary values of nonpulsatile and pulsatile groups are $11.6 \mathrm{gldl}$ and 10.9 gldl, respectively.

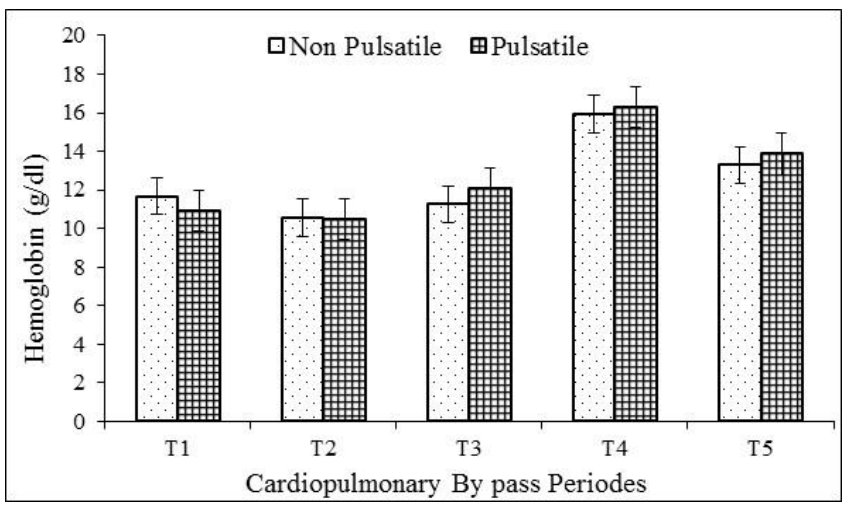

Figure 4. Hemoglobine amounts at 5 different time intervals during Cardiopulmonary By pass operation.

When the operation begins, the average haemoglobin levels of each group decrease due to hemodilution. The measured haemoglobin amounts are $10.5 \mathrm{gldl}$ for nonpulsatile group and $10.4 \mathrm{~g} \backslash \mathrm{dl}$ for pulsatile group. It is known that the amount of hameoglobin generally tends to increase during operation. This study, in parallel, shows that the haemoglobin levels increase in each group in T3. The levels are found to be $11.2 \mathrm{gldl}$ and 12.0 gldl for nonpulsatile and pulsatile groups, respectively. The haemoglobin increase of pulsatile group is found higher. In T4, the haemoglobin levels increase because of giving blood to patients and average haemoglobin amounts are found to be 15.9 e-ISSN: 2148-2683 gldl and 16.3 gldl for nonpulsatile and pulsatile groups, respectively. Following T4, the haemoglobin levels start to decrease and returns to normal levels. In T5, the haemoglobin amounts of nonpulsatile and pulsatile groups are $13.2 \mathrm{gldl}$ and $13.8 \mathrm{~g} \backslash \mathrm{dl}$, respectively. When the differences in haemoglobin levels of T1-T5 are checked, the difference for nonpulsatile group is $1.6 \mathrm{~g} \backslash \mathrm{dl}$. It is $2.9 \mathrm{~g} \backslash \mathrm{dl}$ in pulsatile group. According to these results, it can be said that the type of perfusion affects the amount of haemolglobin even if the effect is small. The study carried out by Driessen and his colleagues had showed that the type of perfusion did not change the amounts of haemoglobin, hematocrit and platelet (Driessen et. al., 1995).

\subsubsection{Hematocrit}

The normal hematocrit rate among children is \% 30-40. Hematocrit rate equals to erythrocyte amount/total blood. it is of vital importance to keep the eryhtrocyte level during operation. Haemoglobin and hematocrit levels are checked constantly by blood gas analyzer. The sudden decrease in hematocrit levels is considered as bleeding. The changes of hematocrit levels are shown in Figure 5.

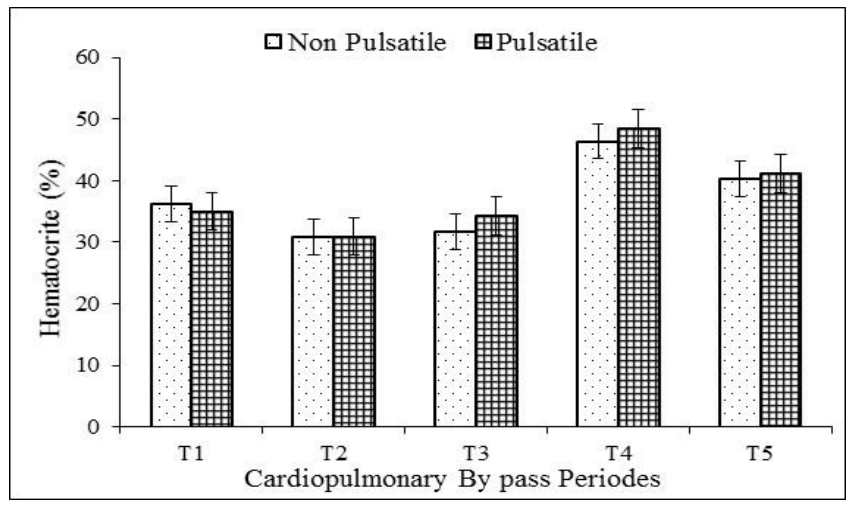

Figure 5. Hematocrit values at 5 different time intervals during Cardiopulmonary By pass operation.

The preliminary average hematocrit rates of nonpulsatile and pulsatile groups are \% 36.1 and \% 35.1, respectively. When open heart surgery begins, both groups exhibit a decrease in hematocrit rates. This can be explained by the application of oxygenator preliminary solution (hemodilution) on patients. In $\mathrm{T} 2$, the heamtocrit rate of nonpulsatile gropu decreases to $\%$ 30.7; it decreases to \% 30.9 among pulsatile group. In T3 when the aortic cross clamping is diclosed, the average hematocrit rate of both groups tend to increase. This is often because of the blood given to patients during operation. In T3, the average hematrocrit rate of nonpulsatile and pulsatile groups are $\% 31.7$ and \% 34.4, respectively. In the first hour of intense care, hematocrit rates increase suddenly since patients are given blood; hematocrit rate of nonpulsatile group becomes \% 46.3 while it is $\% 48.3$ in pulsatile group. In the 24 . Hour of intense care, the hematocrit rates of both groups reach normal levels: \% 40.2 in nonpulsatile group and $\% 41.0$ in the pulsatile one. As it can bee understood from the results obtained, the perfusion type does not change the amounts of eryhtrocyte, haemoglobin, hematocrit and platelet (Driessen et. al., 1995). 


\subsubsection{Platelet (Thrombcytes)}

One of the worst effects after open heart surgery is the decrease in the amount of platelet in blood (Ciaverella et. al., 1990). There are two negative sides of the decrease of platelet. The first one is the risk of coagulation following the adhesion of platalets to extracorporeal circuit; the second one is the high risk of bleeding as a result of loss of platelet (Schmidt et. al., 1961). Besides, studies showed that pediatric bleeding is more prevalent than that of adults (Boldt et. al., 1993). The number of platelets in blood under normal conditions ranges between 170.000 and 380.000. Average platelet amounts for each operation phase obtained by the operations performed within the framework of this study are shown in Figure 6.

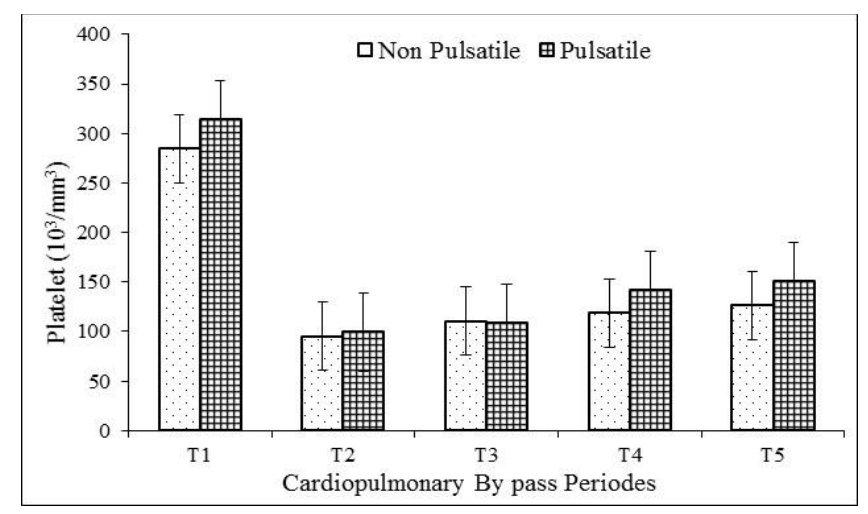

Figure 6. Platelet values at 5 different time intervals during Cardiopulmonary By pass operation.

In $\mathrm{T} 1$, the rates of platelet of nonpulsatile and pulsatile group are measured as $285.000 \mathrm{cell} / \mathrm{mm}^{3}$ and $315.000 \mathrm{cell} / \mathrm{mm}^{3}$, respectively. According to the studies of literature, the amount of platelet rapidly decreases as the operation commences; it drops even by $50-60 \%$. In T2, the amount of platelet of nonoulsatile and pulsatile groups are $95.000 \mathrm{cell} / \mathrm{mm}^{3}$ and $98.000 \mathrm{cell} / \mathrm{mm}^{3}$, respectively. Following this phase, the number of plakets are expected to exhibit a slight decrease or retain its value. Thus, this study demonstrates that the amounts of platelet in T3 are close to those of $\mathrm{T} 2$. The measured average values of platelets of nonpulsatile and pulsatile groups are found to be 110.000 cell $/ \mathrm{mm}^{3}$ and 108.000 cell $/ \mathrm{mm}^{3}$, respectively. In parallel of these, a stable increase in the amounts of platelets of both groups is observed in $\mathrm{T} 4$ and $\mathrm{T} 5$; this increase is higher in pulsatile group. In T4, the average amount of platelet of nonpulsatile and pulsatile groups are found to be $118.000 \mathrm{cell} / \mathrm{mm}^{3}$ and 142.000 cell $/ \mathrm{mm}^{3}$, respectively. In T5, the amounts are $126.000 \mathrm{cell} / \mathrm{mm}^{3}$ and $151.000 \mathrm{cell} / \mathrm{mm}^{3}$ for nonppulsatile and pulsatile groups, respectively.

\section{A General Evaluation and Results on Blood Cells:}

The blood of patients contacts with foreign substances and is exposed to mechanical effects in perfusion during extracorporeal circulation, resulting in changes in blood components. One of the most important changes is the disintegration of red blood cells (haemolysis). When all phases (T1-T5) are checked, no eryhtrocyte loss is detectable in both groups. When the other blood cells are examined, it is not possible to find out a reasonable distinction between the two groups. The results of this study are in compatible with those of literature. Taylor and his colleagues accumulated some experiences from their study which examined the post-pulsatile perfusion results of 200 patients. They found out that a routine pulsatile perfusion having a roller pump system had nothing to do with the decrease in blood cells and platelets (Taylor 1981). According to Song, Driessen and their colleagues, pulsatile and nonpulsatile perfusion are reported to have no effect on the amounts of haemoglobin, platelet and leucocyte (Driessen et. al., 1995), Song\&Wang, 1997). It is detected that the changes in the amounts of blood cells depend on aspiration, working conditions of the system, correct choice of cannule, oxygenator (coated or not), type of operation and biomaterials used for patient's treatment. The rason why blood cell values prove to be bettter in pulsatile group is that pulsatile perfusion provides a better microcirculation and the blood cells join the circulation more in pulsatile perfusion (Kocakulak et. al., 2005; Wright 1995).

\subsubsection{Results of blood proteins}

This section of the study determines the blood proteins obtained at five different time intervals from patients who experience pulsatile and nonpulsatile perfusion. To that end, analysis of total protein, albumin and fibrinogen are realized. All blood counts and analysis of each group consisting of 9 patients are made and the the average of the results of each group are measured. Each parameter coming from these results are discussed and shown below in detail.

\subsubsection{Total Protein}

The normal total protein of children is 5.5-8 g/dl. The average total protein amounts obtained from the operation performed under this study are indicated for each phase in Figure 7.

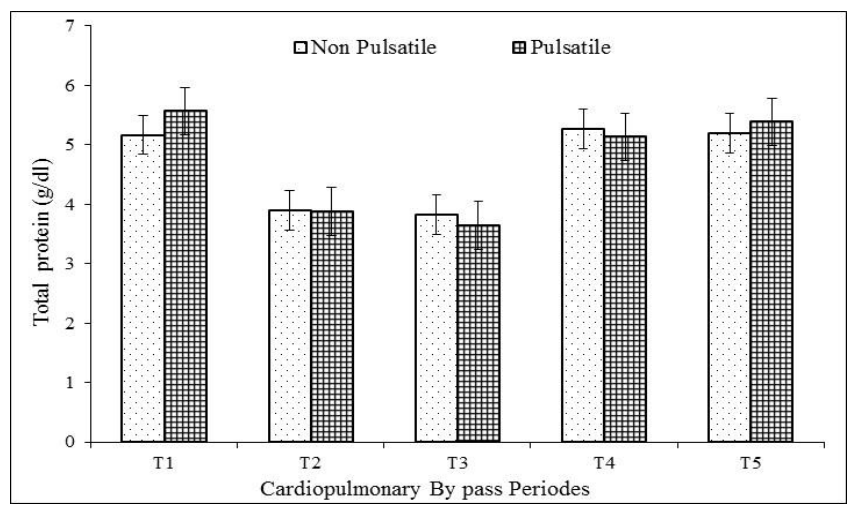

Figure 7. Analysis of Total Protein values at 5 different time intervals during Cardiopulmonary By pass operation.

Before the operation, the average total protein of nonpulsatile group is $5.1 \mathrm{~g} / \mathrm{dl}$ while it is $5.5 \mathrm{~g} / \mathrm{dl}$ in pulsatile group. As the operation starts, the total protein amount decreases as a result of hemodilution and the amount becomes $3.9 \mathrm{~g} / \mathrm{dl}$ in each group in $\mathrm{T} 2$. In $\mathrm{T} 3$, the average total protein amount of nonpulsatile group is found to be $3.8 \mathrm{~g} / \mathrm{dl}$ while it is $3.6 \mathrm{~g} / \mathrm{dl}$ in pulsatile group. In the first hour of intense care, the protein amount reaches normal levels rapidly. The average total protein amounts of nonpulsatile and pulsatile groups are measured as 5.2 $\mathrm{g} / \mathrm{dl}$ and $5.1 \mathrm{~g} / \mathrm{dl}$, respectively. In $\mathrm{T} 5$, the average total protein amounts of nonpulsatile and pulsatile groups become $5.2 \mathrm{~g} / \mathrm{dl}$ and $5.4 \mathrm{~g} / \mathrm{dl}$, respectively. When the phases, T1-T5, are examined for each group, there appears no difference. The type of perfusion does not change the amount of protein. However, the problems arising from the differences between the flow regimes of each perfusion system should not be neglected. 
The way and rate the blood contacts with foreign substance can cause three-dimensional deformation in blood cells and blood proteins. Tanaka and his colleagues reported that not only the quantity but also the conformation change of the adhered proteins influenced the adhesion of platelets (Tanaka et. al., 2000). Moreover, Andrade and his colleagues showed in 1985 that when a foreign substance had a contact with blood, blood adhered to the surface of the foreign substance suddenly and blood-adhered surfaces triggered other formations such as platelet adhesion and coagulation (Andrade\&Hlady, 1987). Starting from this point of view, there appears no such important difference in terms of total protein amounts for each group; it can be also said that pulsatile perfusion brings about less structural changes and adhesions.

\subsubsection{Albumin}

The blood value of albumin, the binding protein in blood, is generally in parallel with total protein amounts. The average albumin amounts obtained from the operation performed under this study are indicated for each operation phase in Figure 8.

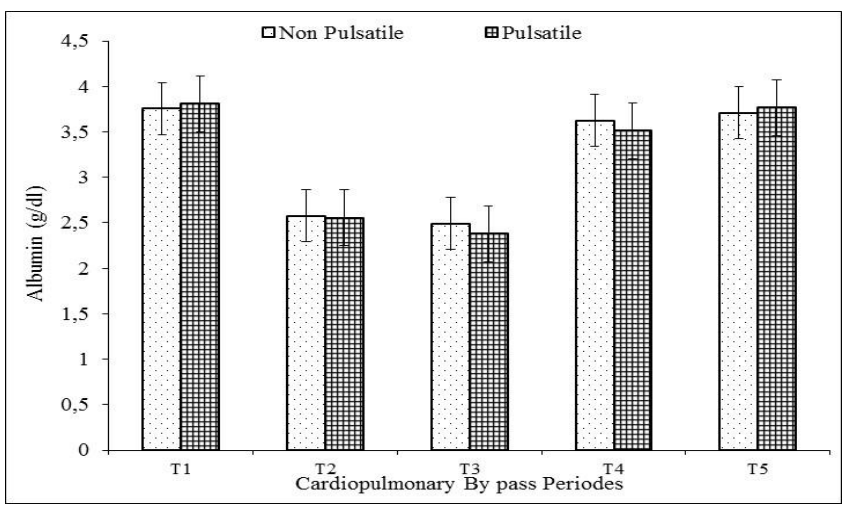

Figure 8. Analysis of Albumin values at 5 different time intervals during Cardiopulmonary By pass operation.

The preliminary albumin amounts of nonpulsatile and pulsatile groups are $3.7 \mathrm{~g} / \mathrm{dl}$ and $3.8 \mathrm{~g} / \mathrm{dl}$, respectively. When the operation begins, the albumin amounts decrease as a result of hemodilution. In T2, the average albumin amount for the two groups is found to be $2.5 \mathrm{~g} / \mathrm{dl}$. Following the disclosure of aortic cross clamping in $\mathrm{T} 3$, the average albumin amounts of nonpulsatile and pulsatile groups are calculated as $2.5 \mathrm{~g} / \mathrm{dl}$ and $2.4 \mathrm{~g} / \mathrm{dl}$, respectively. When intense care commences, the albumin amounts rapidly reach normal levels in parallel with the total protein amount. In $\mathrm{T} 4$, the average albumin amounts of nonpulsatile and pulsatile groups become $3.6 \mathrm{~g} / \mathrm{dl}$ and $3.5 \mathrm{~g} / \mathrm{dl}$, respectively. At the end of the first day in intense care unit, the average albumin value in blood stabilize totally. In T5, the albumin amount of nonpulsatile group is $3.71 \mathrm{~g} / \mathrm{dl}$ while it is $3.76 \mathrm{~g} / \mathrm{dl}$ for pulsatile group. T1-T5 difference between two groups is measured as $0.4 \mathrm{~g} / \mathrm{dl}$. The perfusion type does not change albumin's adhesion to surface and the blood values of the patients.

\subsubsection{Fibrinogen}

Fibrinogen, a component in the coagulation of blood, is the protein which adheres to the surface the easiest when blood encounters foreign substances (Hyde et. al., 1998). The adhered proteins often leads to platelet activation. Under these circumstances, coagulation is formed easier (Niewiarowski $\&$ Holt 1998). The normal values of fibrinogen in blood ranges between $200-450 \mathrm{mg} / \mathrm{dl}$. The average fibrinogen amounts of this study are shown for each operation phase in Figure 9.

The preliminary average fibrinogen amounts of nonpulsatile and pulsatile groups are $257 \mathrm{mg} / \mathrm{dl}$ and $252 \mathrm{mg} / \mathrm{dl}$, respectively. Due to hemodilution, the fibrinogen amount drops by $50 \%$ (Vroman\&Adams, 1969).

In $\mathrm{T} 2$, the average fibrinogen amount of nonpulsatile and pulsatile groups are found to be $157 \mathrm{mg} / \mathrm{dl}$ and $163 \mathrm{mg} / \mathrm{dl}$, respectively. In $\mathrm{T} 3$, this value is retained and the average fibrinogen amounts of nonpulsatile and pulsatile groups are calculated as $154 \mathrm{mg} / \mathrm{dl}$ and $145 \mathrm{mg} / \mathrm{dl}$, respectively.

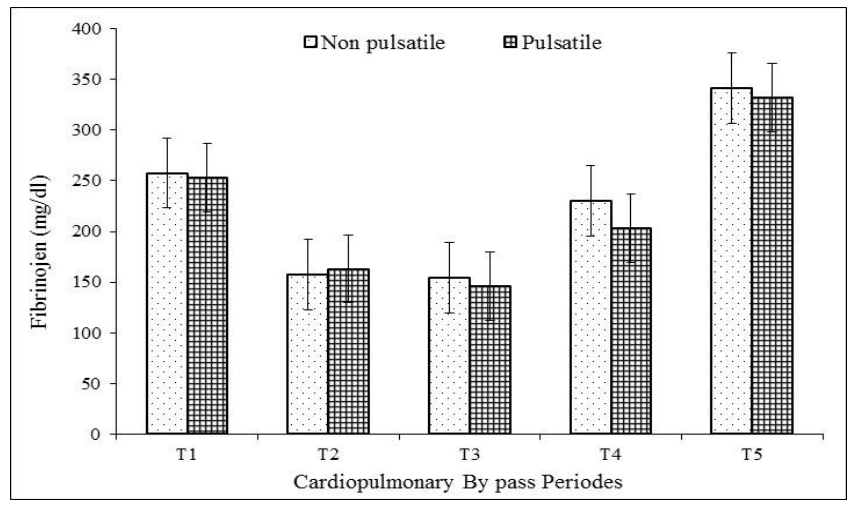

Figure 9. Analysis of Fibrinogen values at 5 different time intervals during Cardiopulmonary By pass operation.

In intense care unit, fibrinogen level of patients start to increase in compliance with anti bleeding drugs and body balance. In T4, the average fibrinogen amounts of nonpulsatile and pulsatile groups become $230 \mathrm{mg} / \mathrm{dl}$ and $202 \mathrm{mg} / \mathrm{dl}$, respectively. This level tends to remain high one week after patients are discharged from hospital. In the first day of intense care, in $\mathrm{T} 5$, the average fibrinogen amounts of nonpulsatile group is $341 \mathrm{mg} / \mathrm{dl}$ while it is $330 \mathrm{mg} / \mathrm{dl}$ in pulsatile group. The type of perfusion does not change the amount of fibrinogen.

\section{A General Evaluation and Results on Blood Proteins:}

When blood test results are evaluated from the angle of all plasma proteins, there appears no meaningful difference in terms of surface adhesion. At th end of first day in intense care unit, the total protein and albumin amounts return to normal levels. The amount of fibrinogen increases beacuse of the durgs given in order to prevent bleeding in intense care. Following proteins' adhesion to surface, the surface characteristics start to change (Vroman\&Adams, 1969). The adhesion of proteins to surface facilitates the activation and adhesion of platelets to surface (Baier\&Dutton, 1969). The coating of surface with heparin or protein derivatives is important for the prevention of blood trauma and adhesion of proteins to surface (Wimmer-Greinecker et. al., 1999). All blood proteins's amounts decrease as a result of hemodilution and blood trauma when bypass starts. 24-hours after the operation, it is observed that the type of perfusion applied on patients does not contribute to the results meaningfully. In this study, it is found out that pulsatile perfusion does not present any difference in terms of the proteins' adhesion to surface and protein loss. 


\subsection{Oxygenator Fibers Study}

The plasma proteins and cells in blood adhere to surface when blood contacts with biomaterial surfaces (WimmerGreinecker et. al., 1999). This is valid for all materials used and during open heart surgery. Oxygenator, one of the materials used during open heart surgery, is one of the equipments which has a dense contact with blood since the large surface area of the fibers inside oxygenator is focus of interest for researches. The surface area in question generally ranges between $1.7 \mathrm{~m}^{2}-2.6 \mathrm{~m}^{2}$ and it provides the oxygenation of blood. The great part of interaction of blood componenets takes place here (Segers et. al., 2001). Therefore, the effects of the method differences and oxygenator types on open heart surgery and healing processes of patients are determined by blood componenets adhered to fibers inside the oxygenator used within the system of open heart surgery. When the patient's blood joins the circulation extracorporeally, the plasma proteins and cells adhere to extracorporeal lines and oxygenator (Kirklin 1983). Oxygenator fibers are one of the places where adhesion of blood occurs. In line with this study, the fibers inside the oxygenator are cut, extracted. The amount of blood adhered to fibers are checked.

After the operation and the stabilization of the patient, the fibers cut from oxygenator are put into $10 \mathrm{ml}$ serum physiological solutions. These solutions are called solutions No. 1 under examination. Then, the solutions of the fibers are renewed with $10 \mathrm{ml}$ serum physiological solutions. The new solutions are called solution No. 2. The fibers in solution No. 2 are sonicated for two hours. The solution sonicated and solution No. 2 are examined on pulsatile and nonpulsatile groups. The results obtained are presented and interpreted in this section below.

\subsubsection{Results of Blood Cells}

This section of the study examines the amounts and behaviours of blood cells adhered to fibers cut from oxygenator used in open heart surgeries.

\subsubsection{Erythrocytes (RBC)}

The average erythrocyte amounts obtained from fibers are shown for each type of operation in Figure 10a and 10b.

The erythtrocyte amounts of nonpulsatile group and pulsatile groups are calculated as 33.880 cell $/ \mathrm{mm}^{3}$ and 26.330 cell $/ \mathrm{mm}^{3}$, respectively. In solution No. 1 while the values of nonpulsatile and pulsatile groups are $2.880 \mathrm{cell} / \mathrm{mm}^{3}$ and 1.630 cell $/ \mathrm{mm}^{3}$, respectively in solution No. 2. Just like the other formed particles, the erythrocyte adhesion is less in pulsatile group.

Due to the blood residuals packed between fibers in solution No. 1 , it is reasonable to see an amount of blood cells. However, when solution No. 1 is removed and solution No. 2 is located and sonicated, the erythrocyte amount calculated is meaningful.

The number of erythrocycyes in nonpulsatile group is higher than that of pulsatile one. The way and rate the blood contacts with foreign substance in pulsatile group can cause deformations in the structure of blood cells. The conformation change in adhered proteins may lead to this outcome as well. This way of interpretation puts forward that open heart surgery with pulsatile perfusion contributes to blood compatibility more than that of nonpulsatile group in terms of erythrocyte cells.
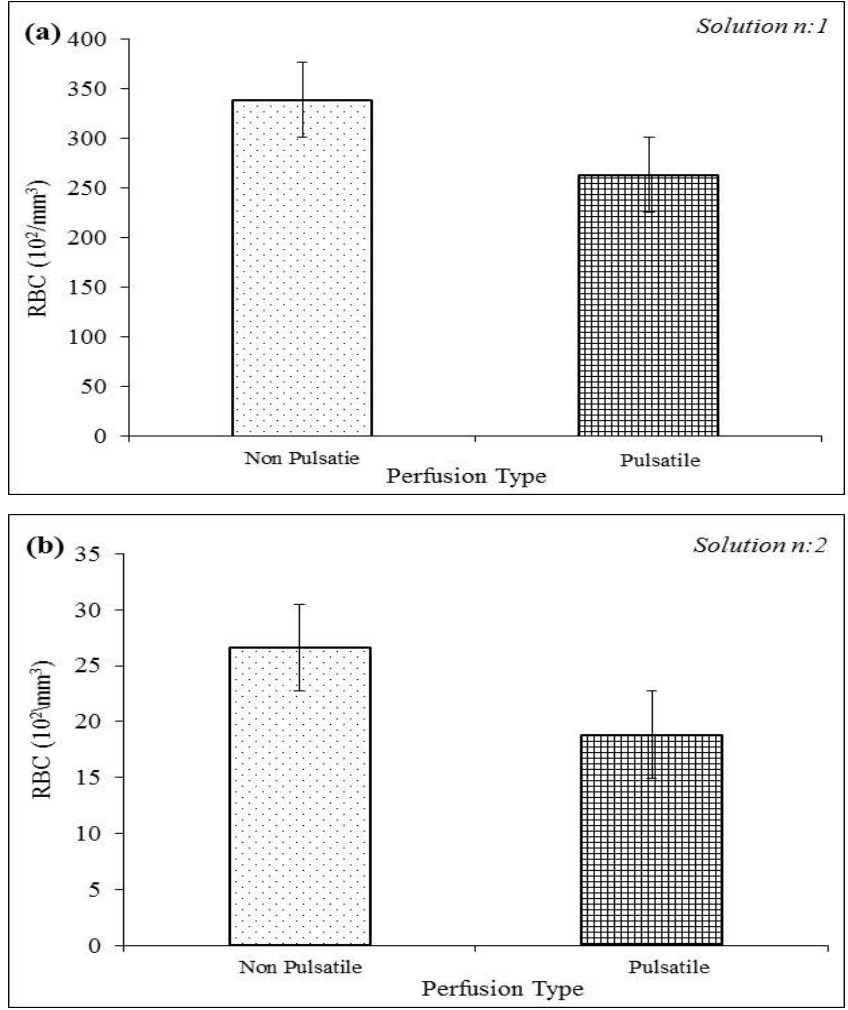

Figure 10. Average RBC cell amounts from fiber surfaces. a) From solution No.1; b) From solution No.2.

\subsubsection{Leucocytes (WBC)}

The average leucocyte amounts obtained from fibers are shown for each type of operation in Figure 11a and 11b.
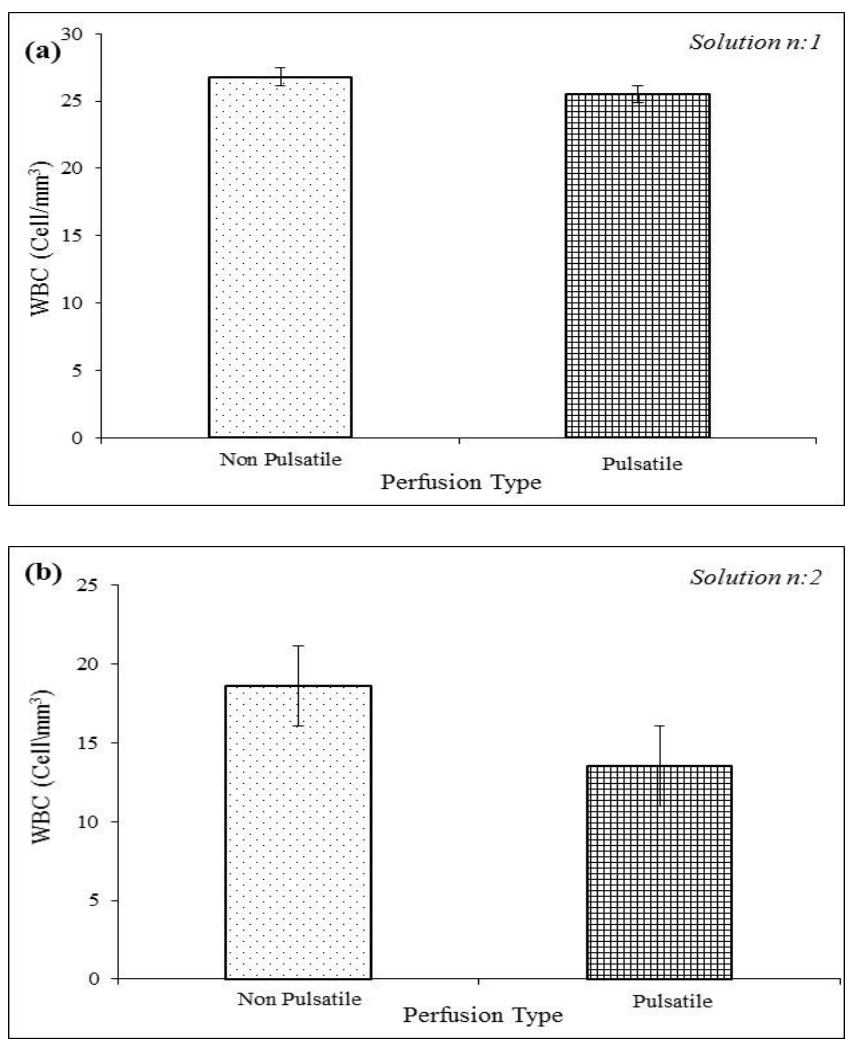

Figure 11. Average WBC cell amounts from fiber surfaces. a) From solution No.1; b) From solution No.2. 
As seen from the figure, the leucocyte amounts of nonpulsatile group and pulsatile groups are calculated as 26.8 cell $/ \mathrm{mm}^{3}$ and $25.5 \mathrm{cell} / \mathrm{mm}^{3}$, respectively. In solution No. 1 while the values of nonpulsatile and pulsatile groups are 18.6 cell $/ \mathrm{mm}^{3}$ and $13.5 \mathrm{cell} / \mathrm{mm}^{3}$, respectively. In solution No. 2 . Since the first solution includes an amount of blood proteins, it is normal to observe a higher value in solution No. 1.

The number of leucocytes in nonpulsatile group is higher than that in pulsatile one. The way and rate the blood contacts with foreign substance in pulsatile group can cause threedimensional deformations in the structure of blood cells. Starting from this point of view, the difference between two groups may lead us to say that pulsatile perfusion is less effective in structural changes and adhesions of blood cells. This way of interpretation puts forward that open heart surgery with pulsatile perfusion contributes to blood compatibility more than that of nonpulsatile group in terms of leucocyte cells.

\subsubsection{Haemoglobin}

The average haemoglobin amounts obtained from fibers are shown for each type of operation in Figure 12a and 12b. The haemoglobin amounts in solutions can be seen in Figures. The haemoglobin amount of nonpulsatile group and pulsatile group in solution No. 1 are very close $(0.1 \mathrm{~g} / \mathrm{dl}, 0.093 \mathrm{~g} / \mathrm{dl}$, respectively). The haemoglobin amount of nonpulsatile group and pulsatile group in solution No. 2 are very close $(0.018 \mathrm{~g} / \mathrm{dl}$, $0.015 \mathrm{~g} / \mathrm{dl}$, respectively). It can be said that the flow type of blood has no effect on blood compatibility in terms of haemoglobin amounts.
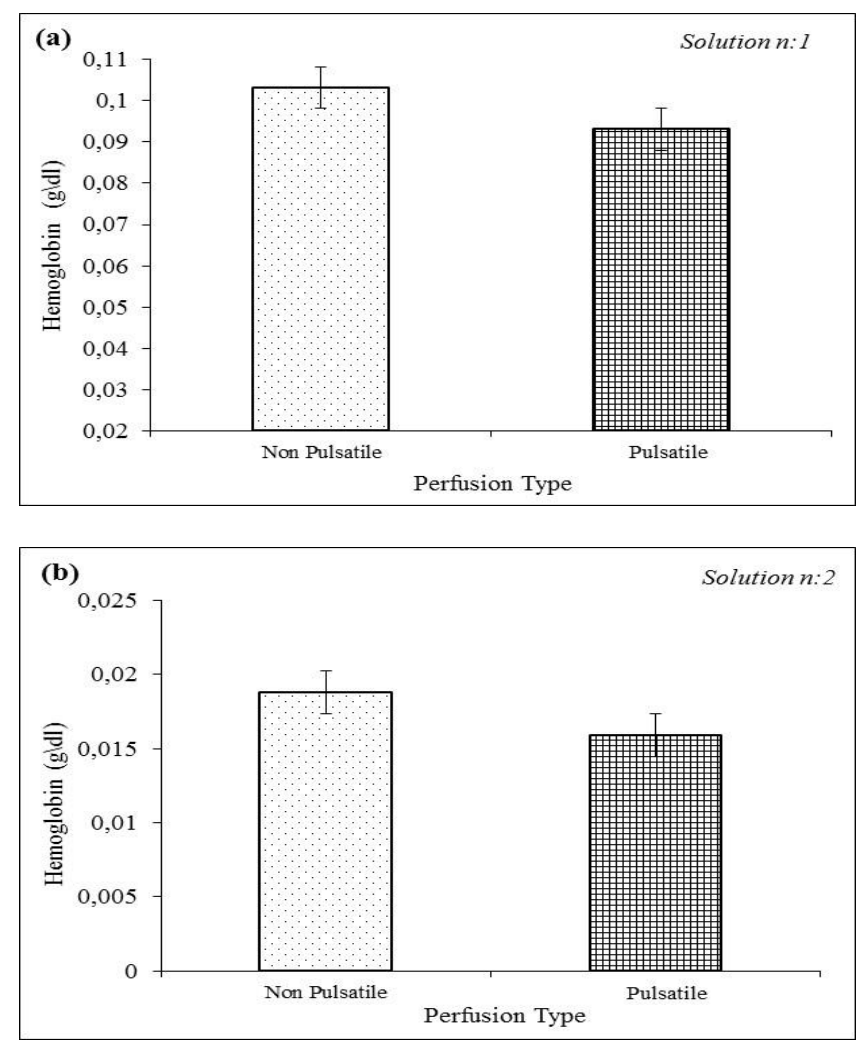

Figure 12. Average Haemoglobin amounts from fibers. a) From solution No.1; b) From solution No.2.

\subsubsection{Hematocrit}

The average hematocrit amounts obtained from fibers are shown for each type of operation in Figure 13. The hematocrit amounts in fiber solutions can be seen in Figure 13a and 13b.

The average hematocrit amount of nonpulsatile and pulsatile groups are $0.233 \%$ and $0.184 \%$, respectively in solution No.1 while the amounts of nonpulsatile and pulsatile groups in solution No. 2 are $0.039 \%$ and $0.029 \%$, respectively.
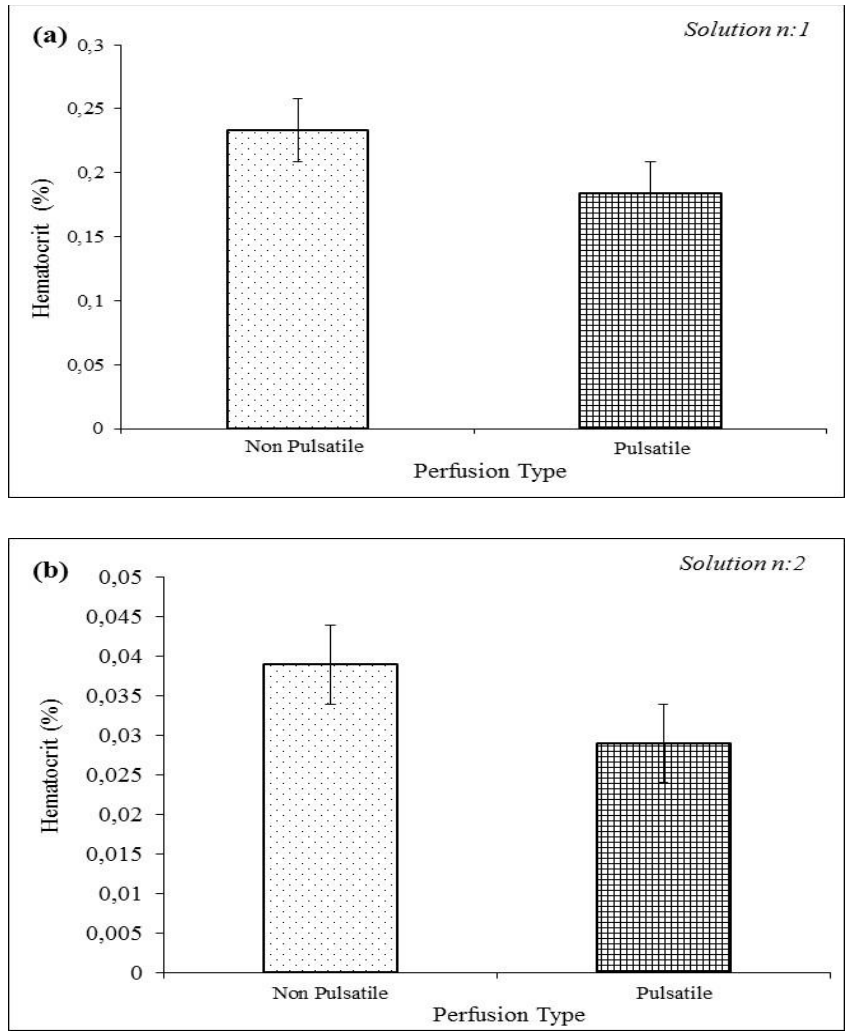

Figure 13. Average hematocrit \% values from fibers. a) From solution No.1; b) From solution No.2

\subsubsection{Platelet}

The average platelet amounts obtained from fibers are shown for each type of operation in Figure 14a and 14b. The average platelet amounts of nonpulsatile group and pulsatile groups are calculated as $3840 \mathrm{cell} / \mathrm{mm}^{3}$ and $3470 \mathrm{cell} / \mathrm{mm}^{3}$, respectively in solution No. 1 while the values of nonpulsatile and pulsatile groups are 330 cell $/ \mathrm{mm}^{3}$ and 310 cell $/ \mathrm{mm}^{3}$, respectively in solution No. 2 .

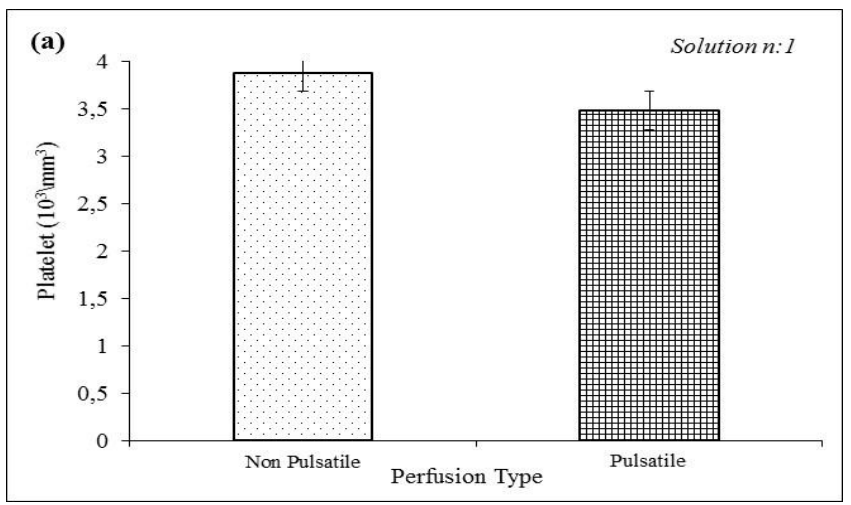




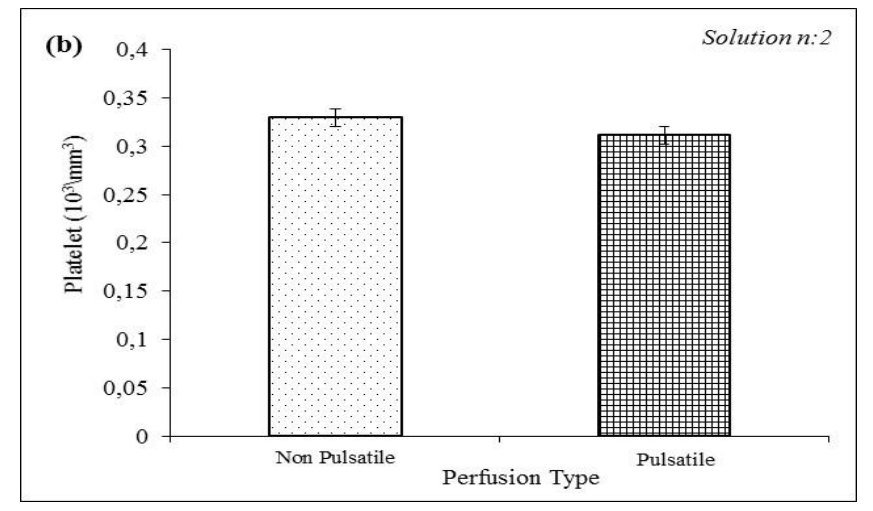

Figure 14. Average Platelet amounts from fibers. a) From solution No.1; b) From solution No.2.

\subsubsection{Results of Blood Proteins}

\subsubsection{Total Protein}

Tanaka M. and his colleagues (Tanaka et. al., 2000) reported in 2000 that the adhesion of plasma proteins to oxygenator and fiber surface is another problem of extracorporeal circulation. Along with proteins adhered to fibers in the first obtained solution, there are blood proteins mixed with solution as well. A seen in Figure 15a, the total amount of protein of nonpulsatile and pulsatile groups are $75 \mathrm{mg} / \mathrm{dl}$ and $79 \mathrm{mg} / \mathrm{dl}$, respectively. The total amounts of protein of both groups of perfusion are close in the first solutions. As seen in Figure 15b, the amounts of protein adhered to fibers are $12,4 \mathrm{mg} / \mathrm{dl}$ in nonpulsatile group and $9 \mathrm{mg} / \mathrm{dl}$ in pulsatile one in solution No. 2 following the sonication process. The difference in value is $3.4 \mathrm{mg} / \mathrm{dl}$.
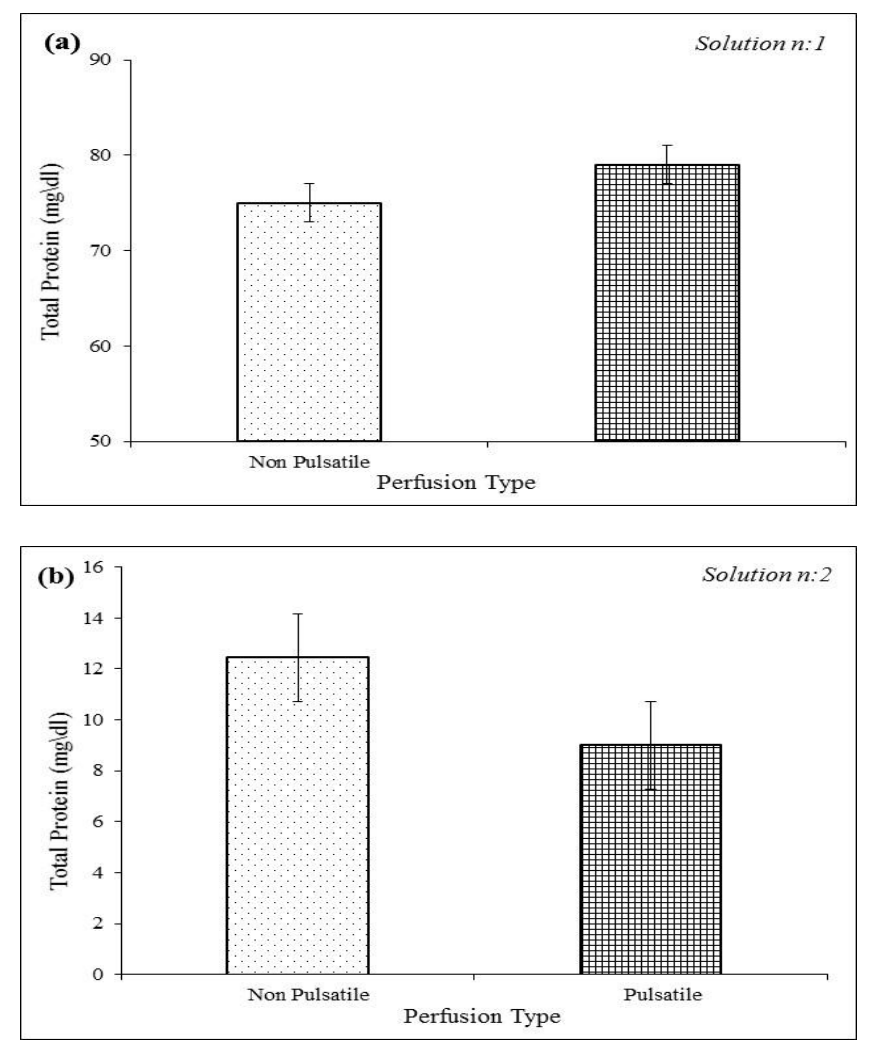

Figure 15. Average of Total Protein amounts of fibers. a) From Solution No. 1; b) From Solution No. 2.

The prevention of adhesion of proteins to surface depends on whether oxygenator is coated or not rather than the type of perfusion. The studies show that the oxygenator's being coated with heparin, PMEA (Poli 2-metoksiethyl acyrilate) or albumin is an important phenomenon in the blood cells' disintegration or adhesion of plasma proteins to surface Kocakulak et. al. 2005; Yan Chan et. al., 2007) . According to the results, the pediatric pulsatile perfusion has no negative effect on the disintegration of formed blood elements and adhesion of plasma proteins to surface. It is not to makesuch a comment since albumin and fibrinogen at microlevels are not detectable in fiber sonicated solutions. This case indicates hoy effective blood flow rate is in the adhesion and disintegration of blood components (Kameneva et. al. 2004; Lotte., et. al., 2018) because even in literature studies with coated oxygenators realized among adults, albumin and fibrinogen were not detected at microlevel in fiber solutions exposed to sonication (Kocakulak et. al. 2002). It is known that pulsatile flow causes low vasculary resistance especially among children, low lactic acid production and a better healing of organs Yasui et. al., Wickramasinghe et. al., Tamagava et. al., 1996; Feng et. al., 2011). The reason why the values of blood cells and blood proteins are better in the group in which pulsatile flow is used is that pulsative perfusion provides a better microcirculation and enables blood cells and/or proteins to join the circulation more. Just as Wright M. and his colleagues did in 1994, M. Kocakulak and his friends reported in 2005 that pulsatile perfusion provided a better microcirculation and this enabled the blood cells and proteins to join the circulation more Kocakulak et. al. 2005; Wright G. 1994; Xiaowei et. al. 2011).

\section{Conclusions and Recommendations}

This study which aims a research on the effects of pulsatile and nonpulsatile perfusion on patients and oxygenator fibers puts forward the results as follows; As a result of the measurements of blood obtained from different phases of open heart surgeries, there appears no meaningful distinction between pulsatile and nonpulsatile perfusion when the results of blood cells such as erythrocyte, leucocyte, platelet, haemoglobin and hematocrit are compared. Pulsatile perfusion has no negative effect on the results of tests of patients. Pulsatile flow with its high energy makes it easier for blood cells to join the circulation. Pulsatile perfused patients have a higher erythrocyte and leucocyte increase even if this increase is not found statisticaly meaningful. Pulsatile perfusion keeps microcirculation open and enables more blood cells to join the circulation. When total protein, albumin and fibrinogen measurements are compared during the examination of blood proteins of patients, it can be seen that the protein amounts are preserved in each group and pulsatile perfusion has no negative effect on the adhesion of blood cells. The solutions obtained after sonication are the amounts of cells adhered to fiber surface. When the results are checked, it is understood that less erythrocyte and leucocyte cells adhere to fiber surfaces in pulsatile perfusion. There occurs more adhesion of blood cells in nonpulsatile perfusion. When the total adhered blood protein amounts of the two groups are compared, the adhesion is less in pulsatile group. The high energy and changeable structure of pulsatile perfusion have a positive effect on oxygenator fibers. The low flow amount in pediatric cardiopulmonary bypass is considered to lead to less turbulent flow, less shear stress and less blood trauma. When all results are checked, the biocompatibility response of pulsatile perfusion is better. Pulsatile perfusion can be securely benefited in pediatric cardiopulmonary bypass. 


\section{References}

Andrade JD, Hlady V., (1987) Plasma protein adsorption: the big twelve. Ann N Y Acad Sci.; 516:158-72.

Baier RE, Dutton RC. (1969), Initial events in interactions of blood with a foreign surface, J Biomed Mater Res, 3, 191206

Boldt J, Knothe C, Zickmann B, Bill S, Dapper F, Hempelmann G., (1993) Platelet function in cardiac surgery: influence of temperature and aprotinin. Ann Thorac Surg. Mar, 55 (3), :652-8.

Ciaverella D, Snyder EL. Effects ofcardiopulmonary bypass on platelet function (1990), Dutcher JP ed. Modern transfusion therapy. BocaRaton, FL: CRC Press, 3-23.

Driessen J, Dhaese H, Fransen G, Verrelst P, Rondelez L, Gevaert L,(1995) Pulsatile compared with nonpulsatile perfusion using a centrifugal pump for cardiopulmonary bypass during coronary artery bypass grafting. Effects on systemic haemodynamics, oxygenation and inflamatory response parameters, Perfusion, 10:3-12.

Dündar Akif, Frazier OH, Charles D Fraser JR (1999). Defining Pulsatile Perfusion, Quantification in Terms of Energy Equivalent Pressure, Artificial Organs, 23 (8),712-716

Feng Qiu, Sameer Khan, Jonathan Talor, Allan Kunselman, Akif Ündar, (2011), Evaluation of two pediatric polymethyl pentene membrane oxygenators with pulsatile and nonpulsatile perfusion, Perfusion, 26 (3) 229-237.

Hyde JAJ, Achinn J, Timothy RG, (1998). Platelets and Cardiopulmnary Bypass, Perfusion, 13, 389-407

K. X. Qian, (1994) Pulsatile blood flow from impeller pump: A dream has come true. Journal of Biomaterials Applications, 9(2), 158-177.

K. X. Qian, (1995) Pulsatile centrifugal impeller heart a successful application of engineering to medicine, Biomedical Engineering Applications. Basis Communica-tions, 7(3), 263-275.

Kameneva Marina, Burgreen G, Kono K, Repko B, Antaki F, Umezu M (2004). ASAIO Journal, 50, 418-423

Kirklin J, Westaby S, Blackstone E, (1983), Complement and the damaging effects of cardiopulmonary bypass, $J$ Thorac Cardiovasc Surg 86:245

Kocakulak M, Askın G, Küçükaksu S, Tarcan O, Piskin E., (2005). Pulsatile Flow Improves Renal Function in High Risk Cardiac Operations, Blood Purification 23: 263-267.

Kocakulak, M., Koçum, C., Saber, R., Ayhan, H., Günaydın, S., Sarı, T., Zorlutuna, Y., Bingöl, N., (2002) Investigation of Blood Compatibility of PMEA Coated Extracorporeal Circuits, Journal of Bioactive and Compatible Polymers, 17, 343-355,

Lotte Schraven, Andreas Kaesler, Christian Flege, R€udger Kopp, Thomas Schmitz-Rode, Ulrich Steinseifer, Jutta Arens, (2018), Effects of Pulsatile Blood Flow on Oxygenator Performance Artificial Organ, 42(4):410-419.

Martin R, McKenty S, Thisdale Y, Lavallee P, Teijeira J, Bonneau D, Tetrault JP., (1989), Hemolysis during cardiopulmonary bypass. $J$ Cardiothorac Anesth. Dec;3(6):737-40.

Niewiarowski S, Holt JC (1987). Biochemistry and Physiology of Secreted Platelet Proteins, Philadelphia: JB Lippincott, 618-630.

Quiroga MM, Miyagishima R, Haendschen LC, Glovsky M, Martin BA, Hogg JC. (1985 Jul), The effect of body temperature on leukocyte kinetics during cardiopulmonary bypass. J Thorac Cardiovasc Surg. 90(1) 91-6.

Schmidt PJ, Peden JC, Brecher G, Baranovski A. (1961) Thrombocytopenia and bleeding tendency after extracorporeal circulation. J Med; 265: 1181-85.

Segers PAM, Heida JF, de Vries I, Maas C, Boogart A.J., Eialander S. (2001). NeSeCC Journal,26, 10-16.

Song Z, Wang C, Stammers AH. (1997) Clinical comparison of pulsatile and non-pulsatile perfusion during cardiopulmonary bypass. J Extra-Corporeal Tech, 29:17075.

Tamagava M, Akamatsu T, Saitoh K, (1996), Prediction of hemolysis in turbulent shear orifice flow, Artif Organs 20, 553-559.

Tanaka M, Motomura T, Kawada M, Anzai T, Kasori Y, Shiroya T, Shimura K, Onishi M, Mochizuki A. (2000 Jul), Blood compatible aspects of poly(2-methoxyethylacrylate) (PMEA)--relationship between protein adsorption and platelet adhesion on PMEA surface. Biomaterials.; 21(14):1471-81.

Taylor KM. (1981). Pulsatile cardiopulmonary bypass: A review. J Cardiovasc Surg; 22, 561-8.

Vroman L, Adams AL, (1969). Identification of rapid changes at plasma-solid surfaces, J Biomed Mater Res 1969,3, 43-67

Wickramasinghe SR, Garcia J.D., Binbing Han (2002). Mass and Momentum Transfer in Hollow Fiber Blood Oxygenator, Journal of Membrane Science, 208, 247-256

Wimmer-Greinecker Gerhard, Georg Matheis, Sven Martens, Gerhard Oremek, Ulf Abdel-Rahmana, Anton Moritz, (1999) European Journal of Cardio-thoracic Surgery 16 211-217

Wright G. (1986) Blood cell trauma. In: Taylor KM, eds. Cardiopulmonary Bypass: Principles and management. London: Chapman and Hall; p. 249-76.

Wright G. (1994), Hemodynamic analysis could resolve the pulsatile blood flow controversy. Ann Thorac Surg. 58: 1199-1204

Wright G. (1995). The assessment of pulsatile blood flow. Perfusion, 10: 135-140

Xıaowei W. Su, Yulong Guan, Mollıe Barnes, J. Brıan Clark, John L. Myers, And Akif Undar, (2011), Improved Cerebral Oxygen Saturation and Blood Flow Pulsatility With Pulsatile Perfusion During Pediatric Cardiopulmonary Bypass, Pediatrlc Research, Vol. 70, No. 2.

Yan Chan, Hideki Fujioka, Ronald B. Hirshl, Robert H. Bartlett, James B. Grotberg, (2007), Pulsatile Blood Flow and Gas Exchange Across a Cylindrical Fiber Array Kit, J Biomech Eng., 129 (5): 676-687.

Yasui H, Yonenaga K., Kado H., Ando H., Mizoguchi Y, Honda S., (1989). Open heart surgery in infants using pulsatile high flow cardiopulmonary bypass, J Cardiovasc Surg.,30, 661668. 